\title{
Exhibiting the West at the Paris Exposition of 1867: Towards a New American Aesthetic Identity?
}

\section{François Brunet and Jessica Talley}

\section{(2) OpenEdition \\ Journals}

\section{Electronic version}

URL: https://journals.openedition.org/transatlantica/11280

DOI: 10.4000/transatlantica. 11280

ISSN: 1765-2766

Publisher

Association française d'Etudes Américaines (AFEA)

\section{Electronic reference}

François Brunet and Jessica Talley, "Exhibiting the West at the Paris Exposition of 1867: Towards a New American Aesthetic Identity?", Transatlantica [Online], 2 | 2017, Online since 11 June 2019, connection on 31 January 2023. URL: http://journals.openedition.org/transatlantica/11280 ; DOI: https://doi.org/10.4000/transatlantica. 11280

This text was automatically generated on 31 January 2023.

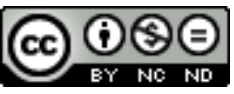

Creative Commons - Attribution-NonCommercial-NoDerivatives 4.0 International - CC BY-NC-ND 4.0 https://creativecommons.org/licenses/by-nc-nd/4.0/ 


\title{
Exhibiting the West at the Paris Exposition of 1867: Towards a New American Aesthetic Identity?
}

\author{
François Brunet and Jessica Talley
}

\section{Introduction}

1 The Paris Exposition Universelle of $1867^{1}$ was, according to historian Volker Barth, "the most consistent attempt ever made to literally create a world exhibition" (Barth 23). The second World's Fair of the French Second Empire brought together approximately 50,000 exhibitors from 32 countries and attracted an estimated 11 million visitors over eight months. It attempted to cover everything everywhere: Europe, the Americas, Africa, and Asia competed in all fields of endeavor, from industry to fine art but also social organizations and cultural heritages. In contrast to the 1855 Exposition, dominated by the race to match British industrialization, in 1867 the Empire's "social" doctrine, embodied by the Exposition's organizers, economist Michel Chevalier and engineer Frédéric Le Play, staged industry and labor not only as economic values but as cultural facts, envisioned in socio-ethnographic terms if not as forms of spectacle. The gigantic elliptical Palace was arranged as a panoptical machine, which seemed designed to illustrate Karl Marx's analysis of "commodity fetishism" in Das Kapital, published in 1867. Inside the Palace, the displays followed a double pattern, geographic and encyclopedic, materializing two prescribed readings: comparative surveys of a given "group" or theme, if one followed one of the elliptical rings (from the outer ring with the Gallery of Labor and machines to the Fine Arts around the inner garden); and complete images of nations (if one followed a "wedge" from outer ring to inner garden). The surrounding Champ de Mars was a landscaped park, with dozens of national pavilions-an innovation that would become a staple of later World's Fairsalong with thematic and pleasure features. Also included for the first time were live performances by "ethnic" subjects. The Empire intended this Expo to demonstrate to the world the power of a modernized but pacific nation, the success of its mixture of 
laissez-faire and social paternalism, the happy wedding of art and industry, and the preeminence of French taste. Considered a success by the regime, a distraction by its opponents, the "great globalizing event of the decade" (Van Zante 11) was to be judged in retrospect a swansong of the Empire, seen as celebrating "modernity" as a mask for social exclusion, economic failure, military perils, and a deeper misunderstanding of the times ${ }^{2}$.

Figure 1

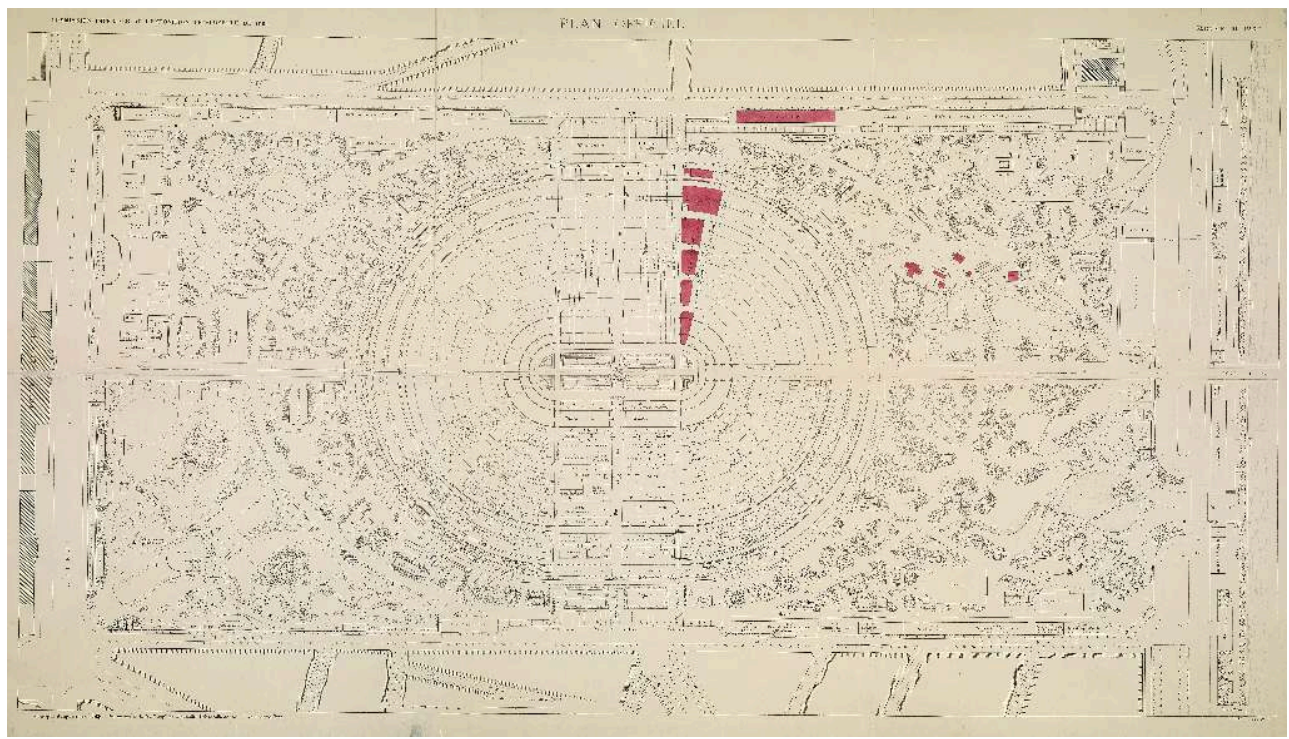

Fold-out floor plan of the 1867 Fair grounds («Plan officiel » by A. Gaudriot and L. Dardoize,

Commission impériale) inserted in album, "Photographs of the American exhibits on display at the Exposition," [1867]. The areas tinted in red watercolor showed the spaces occupied by US exhibits.

Courtesy of the Smithsonian Libraries, Washington, D.C.

2 In this grand French scheme the United States was only a second-tier player, as evidenced by the small overall space occupied by American exhibits (Figure 1) and the relative scarcity of written commentary. For their organizers, however, the Paris Exposition was a crucial opportunity. Just emerging from the Civil War, the US was entering Reconstruction. At first the Paris Exposition was the least of its concerns; decisions were slow, and organization (which had been entrusted exclusively to national governments) chaotic. A small group of civic leaders, politicians and entrepreneurs from the Atlantic seaboard and some Western states and territories, joined by Louisiana, eventually persuaded Congress that after the Union had been on the brink of dismemberment this Exposition was a unique opportunity to recreate a positive national image, and particularly what we will call an aesthetic identity, in proportion to the Republic's space and ambitions towards European markets, public opinions and tastes. In the end, the American participation, albeit modest, was bigger and more diverse in its displays than in 1862 in London, where the US had been severely hampered by the Civil War. While bowing to European hegemony, it sought to combat predominantly negative perceptions of American culture, and to stake out a claim for the country as a land of opportunity, a recovering economic power, and a rejuvenated political culture, now emancipated from slavery ${ }^{3}$.

3 The more than 800 American exhibits featured machinery (railroad engines and cars, steam engines, reapers, sewing machines, telegraph apparatus, safes, and so on), 
cultural equipment (pianos, books and education supplies, scientific instruments), natural resources (large collections of ores, especially from Western territories, as well as grains and cotton). There were also a great many photographs and a sizeable exhibition of painting-the latter considered a failure by French critics, as we shall see. Three feats of organization received a Grand Prize each: the Transatlantic cable, completed in 1866; the Sanitary Commission, an organization for aid to the wounded during the Civil War; and, as an example of "social harmony," the textile factory Pacific Mills of Lawrence, Massachusetts. At the American café Parisian diners did not always enjoy the food, but the "soda fountain" became a fad, while African-American waiters drew a lot of attention. Despite the small size of the US participation, quite a bit of negative judgment (even by American visitors ${ }^{4}$ ), and a lot of indifference, the American organizers had ample reason to consider this Exposition a success for their exhibitors, who received 5 Grand Prizes, 17 gold medals, 75 silver medals, and so on. As the American Commissioner General Nelson M. Beckwith was proud to point out, the US earned the highest ratio of awards to exhibitors after France (Beckwith 8-9). This relative success was reflected in the marked eulogium of American society included in Michel Chevalier's general report on the Exposition (Chevalier LXVff., CIVf., CLXXIVff., CCCXXIff., CDVff). It would be further confirmed at the next World's Fair, in Vienna in 1873, and inspire the organization, in 1876 in Philadelphia, of the first World's Fair on US soil. The present essay chooses to focus on the particular share of the American West-which was a novel presence, as compared with previous World's Fairs-in this mitigated success, while suggesting a reading of the Fair that draws away from simplistic notions of success and failure.

Historian Volker Barth sees in the 1867 Exposition an almost perfect example of what Michel Foucault called a "heterotopia": "a kind of effectively enacted utopia in which the real sites, all the other real sites that can be found within the culture, are simultaneously represented, contested, and inverted." Barth emphasizes the "multiple semantic structures" of the Exposition, "the simultaneity of overlapping medial entities and the [diverse] perceptual practices that these gave rise to" (Barth 24-26). Our argument concurs with Barth's, excluding simplistic readings of the Exposition as either copy of the real world or staged ideological fabrication. We adopt his characterization of the Exposition as a site of "ruptures": between the intentions and the medial structures that embodied them; between the medial structures and public perceptive practices; between an illusion of "total control" by organizers and the "creative element" inherent in visitors' imaginations and memories-a form of appropriation. Next to the failure of American artists, then, one needs to pay attention to the relative success of the rest of the American contribution-and most particularly that pertaining to the West-in the eyes of the juries and portions of the general public. This situation can be seen as an example of "discordance" in the sense defined by Christophe Charle (2011) in his analysis of modernity ${ }^{5}$. Leaving notions of failure and success aside, we question the American presence at the Exposition as a complex, contradictory moment, condensing the slow emergence of the US in larger processes of globalization and modernity. In this moment, we suggest, the US is seen-or at least, is exhibited with the intention to be seen-as a new actor on the world stage, with an aura of rising technological, territorial and commercial power; the complex image of a Republic incorporating racial diversity otherwise known only in colonial empires; and a potential for aesthetic appeal, yet uncertain but perceptible. This latter concern with aesthetics and the visual stems from the preeminence of art-or the "collision of art 
and politics" (Mainardi 1)-and the ubiquity of photography and visual communication in the Empire's "fête" (see Demeulenaere-Douyère in Carré 431-433). It leads us to interrogate the ways in which American exhibitors tried to fashion their primarily economic and political motives in artistically-minded objects and images, particularly in the representation of the West. Thus the discussion that follows seeks to identify aesthetic concerns-i.e., concerns with beauty, style, more generally an ambition to seduce the gaze of French and international viewers-among the general organization and specific displays of the American exhibition, concentrating on exhibits offered by the Western states and territories (from Illinois westward). Indeed, such attempts to please, and perhaps to transform, the French imagination appear to have been especially prominent among exhibitors who displayed and promoted the new landscapes, along with the new riches, of the trans-Mississippi West. As we will argue, indeed, images and objects from Western states and territories-particularly between the Rocky Mountains and California-played a significant, if perhaps unexpected, role in shaping a new aesthetic identity that potentially extended to the entire US exhibition.

\section{All Economics And no Aesthetics?}

5 To bring up the notion of a Western aesthetics, or of an American aesthetics, in the context of Second-Empire France is a provocation of sorts. By 1867, the most influential French opinion was-in the wake of the recent Civil War, viewed as a global conflict between "Anglo-Saxon" imperialism and a threatened "Latin" world-on the downside of its "reticent fascination" with America (Portes). Even Tocquevillians did not avoid the dominant cliché that American culture was, in short, practical and business-minded but tasteless and showy-material and provincial (Roger 100-137). As the journalist Duvergier de Hauranne wrote in 1865, Americans could be compared "to their machines, which are powerful, but somewhat roughly built, excellent to produce objects of ordinary quality and common use, but inapplicable to the brilliant imaginations of European luxury" (Duvergier 87). The cultural critique of America went deeper. Critics of the 1860s used the phrase "American images," as Philippe Hamon has shown, as a generic label for all kinds of images, American or not in origin, that manifested negative aesthetic values from circus shows to early Impressionnist paintings. In this proto-critique of what the Frankfurt School would later call the culture industry, claims to commercialism, vulgarization, naivety, became associated either metaphorically or by a loose causal link with "America" (Hamon 235-248). ${ }^{6}$ For the post-romantic avant-garde, "America" simply stood for modernity and its discontents. Universal Expositions in general were lambasted as triumphs of "matter" and "Americanization," a term coined by Charles Baudelaire in the context of the 1855 World's Fair (Roger 93-98). ${ }^{7}$ In January 1867, the diary of the Goncourt brothers described in advance the Exposition as "the last stroke to what is, the Americanization of France, industry winning over art, the steam reaper cutting at the place of a picture, chamber pots under cover and statues out in the open-in one word, the Federation of Matter" (Goncourt 64). Later in 1867, Gustave Flaubert wrote to George Sand that while at the Expo he "thought the whole time of America" and felt like "speaking Negro" (Flaubert 635-636), as if identifying with an oppressed minority-precisely at the time 
when the US, as both a racialist and a newly multi-racial civic society, was emerging as an alternative model for imperial France.

In 1867 the Exposition was bound to reflect this widespread opinion. In March, ahead of the opening, the popular L'Illustration wrote: "It is not with luxury items or art objects that the American Union will shine at the Champ de Mars; nobody will say the contrary, and she admits it herself; but it is not without reason that she counts on drawing attention to the products of its mining and agricultural industries" (L'Illustration, 1867, 199). Commissioner Beckwith, a long-time Paris resident, had interiorized this aesthetic complex from the start, and in his final survey could only repeat it. The "high position" of American industrial products in the juries' opinions was, he admitted:

not due in general to graceful design, fertile combinations of pleasing colors, elegant forms, elaborate finish, or any of the artistic qualities which cultivate the taste and refine the feelings by awakening in the mind a higher sense of beauty, but it is owing to their skillful, direct, and admirable adaptation to the great wants they are intended to supply, and to the originality and fertility of invention which converts the elements and natural forces to the commonest uses, multiplying results and diminishing toil (Beckwith 9). ${ }^{8}$

Obvious evidence for Beckwith's thesis is in the poor rating given to the American fine arts exhibition-the largest display of the kind presented to date in Europe, and to this day about the only part of the US participation to this Expo with a significant historiographical trail (see Troyen; Cohen-Solal). Despite the "Artists medal" awarded to Frederick E. Church's Niagara and the attention raised by James McNeill Whistler's White Girl, this show excited few comments. The very small snippets of review we have on record are mostly negative-an attitude of ignorance or contempt that was perfectly captured in the odd vantage point chosen by the Exposition's stereographers Léon et Lévy (where we notice, besides a statue of Napoleon I, J.A. Ward's Indian Hunter, Figure 2).

Figure 2

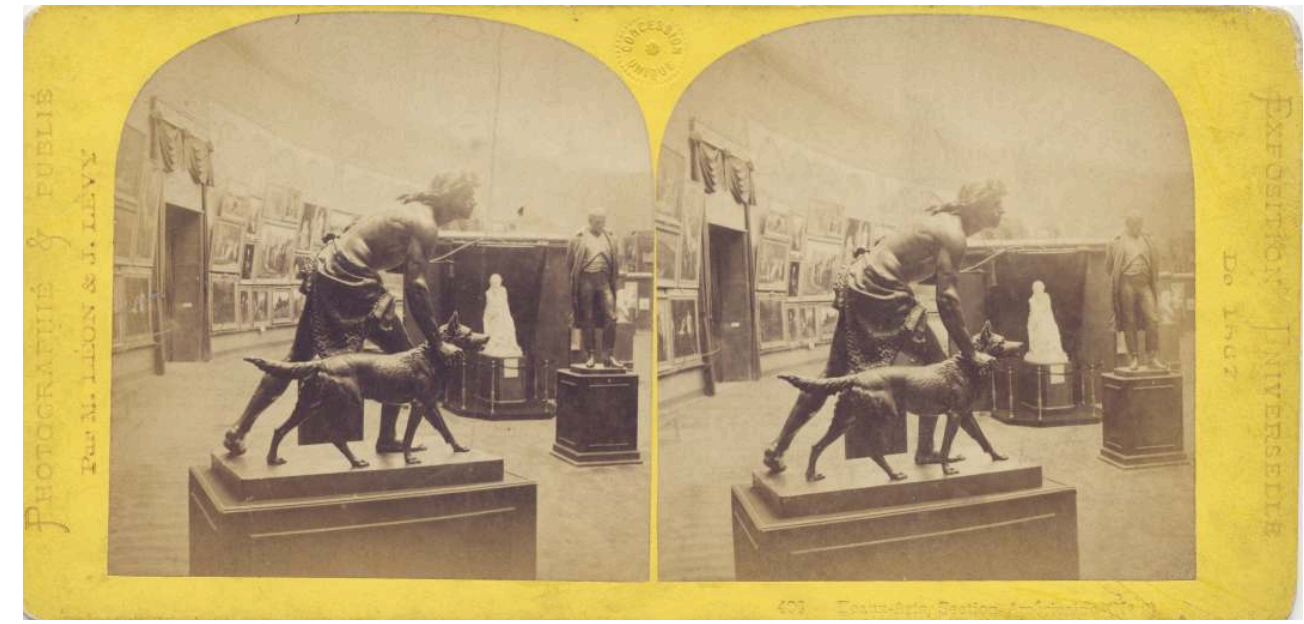

Léon et Lévy, Exposition universelle de 1867, No. 406, «Beaux-Arts, Section Américaine ( $n^{\circ} 2$ ) », stereoscopic view on paper on card mount.

Private collection

7 Ernest Chesneau, secretary of the jury for Class 1, concluded that the American school was "laboriously trailing behind the English school"-though he grouped it, following the geopolitically-determined layout of the Palace, with "the schools of the South." To 
Chesneau, save for a few examples of "boldness" such as Church's Niagara and Bierstadt's Rocky Mountains (the only definite Western picture in the show, though some others of the many landscapes presented were associated to the West by some viewers), "most American landscapes are painted in a spirit of convention that is surprising in a nation that is supposed to have freed itself of so many other conventions" (Chesneau 161-162). ${ }^{9}$ Although reviewers noted this abundance of landscapes, and although Church and Bierstadt did leave a trace in subsequent French art-historical texts ${ }^{10}$, in the 1867 landscape, a "road not taken" (Mainardi 175-186), yielded to genre, and French critics generally considered that American artists were imitators, either of the English school or the "continental" one. In her classic study, Carol Troyen concludes that in 1867 American artists, obsessed with recognition from Paris, and inspired (mostly) by academic masters, were still "innocents abroad," like the characters of Mark Twain's novel by that title (who visit the Fair during the course of their Great Excursion)though the art historian also points out that the Expo witnessed the rise of a new generation, less interested in grand style landscapes than in small genre pictures, and groping for a proto-Impressionist style. Troyen, however, notes the discordant voice of Théophile Thoré in his 1870 Salons de W. Burger: "The Americans have no art? All the better! They won't be afraid to make something new, and it is well possible that the boys of this country of liberty will one day address themselves to the task of creating extraordinary paintings" (cited by Troyen 16). ${ }^{11}$ Without prolonging this discussion, we make a note of Chesneau's bemusement at the "conventionality" of self-proclaimed non-conventionals, and Thoré's opposition to this simplistic reading. Such contrasts of opinion point to the "multiple perceptions" mentioned earlier, which as we shall see the displays from the West elicited more particularly. Certainly worth noting, in the analysis of such contrasts, is the near-total absence of Western subjects in the US fine arts exhibition of 1867. Not only were there almost no Western landscapes, but even Native American figures, so conspicuous in Parisian salons and exhibitions since the beginning of the century (Cabau 39-107), were almost entirely missing, if one excepts Ward's Indian Hunter. Furthermore, although it seems that initial plans included a delegation of Native Americans, and although some iconographical and written traces allude to the presence of "Redskins" in Paris, such presence appears to have been brief, unofficial, relatively inconspicuous, and probably fabricated. ${ }^{12}$ If a Western aesthetics did emerge in 1867, it was not in the Fine Arts section, nor as a reflection of the older Romantic taste for primitivism, but rather in a diverse array of thematic, material, and photographic exhibits.

\section{A New Western Aesthetics?}

The representation of the American West in Paris in 1867 marked a turning point-or at least a moment of complexification and diversification-in French (and European) perceptions, owing to several factors that include the dawn of a mass visual culture. This shift could perhaps be characterized, very broadly, as a transition between what had been an idea or a myth in Henry Nash Smith's sense and a more concrete, materially and territorially based set of representations, evoking some differences between various regions of the West. French perception of what had long been called, very vaguely, "the West," had long been very diffuse, not geographically specific. It had been largely shaped by the influence of major writers and artists-from Chateaubriand and Tocqueville to Delacroix-working in the Romantic tradition and primarily concerned 
by the motif of the "Vanishing Indian," which according to Tangi Villerbu's synthesis formed the core of a "French narrative" of not just the West but the American nation. Above all other influences, Villerbu stresses, the fictional world created by James Fenimore Cooper's Leatherstocking Tales offered to cultivated Europeans a seductive and compelling aesthetic framework for the history and even the geography of the American West, to the extent that from 1830 on "all discourse on the West produced in France bears the mark of Cooper" (Villerbu 98-100). The Last of the Mohicans and its companion volumes served to construct an aesthetic idea of "the West" and, by extension, "America," that was the base for all later representations and grew into an early culture industry in the following decades (Villerbu 96). Along with French and European iconography, visits and performances by Native Americans in Paris had helped popularize the "Mohican" and other "Indian" figures as Parisian staples. It was this well-established French narrative, centered on the doom of the "noble race" at the hands of Anglo imperialism, that the displays from several Western states and territories came to modify in 1867.

9 An ensemble of objects and pictures that was by far the most concrete presentation of the West-including the Midwest, the Rocky Mountain area, and the Pacific Coast-in Europe to date, these displays offered a shift from a primarily intangible idea of a generic "West" to a much more physical identity. As Villerbu stresses, the shift resulted primarily, in 1867, from "the self-expression [of the US] offered to foreign gazes." This organized representation followed the norm of World's Fairs in that it was primarily material: the West was presented by way of "industrial and artistic objects, photographs, and agents of its development," as we will detail in the following pages. This was a concerted decision on the part of American organizers, and one that clearly looked to the future: as Villerbu writes, while "American exhibitors could have easily continued to pander to the European fascination with Native Americans and the exoticism attached to the American past," they chose "to portray the West with a forward-looking vision" (Villerbu 121). We suggest, in turn, that Western exhibitors utilized the stage of the Exposition to present a new, reformed Western aesthetics, built not on history but on geography and above all on natural resources.

10 To be sure, this new aesthetics included images of Western landscapes. These landscapes, however, were no longer stages for a Romantic drama of (Indian) nature vs. (Euro-American) civilization, nor its later, Buffalo-Bill-like, evolution into a theater of lawless violence on the frontier; rather they served as pictorial contexts for the objects, both raw and finished, that formed the core of the Western exhibits. Photographs, rather than paintings, were the primary exemplars of this evolving, forward-looking vision of the West. While the more developed and populated Eastern states promoted their fabricated goods and works of art, Western exhibitors took to boostering-selling an idea combining wilderness and economic promise through the exhibition of natural resources and photographs. These early instances of Western boosterism in Paris arguably participated in forming a groundwork for a new aesthetics of the West, later to be combined with the older "Indian" motif in the mass spectacles of Buffalo Bill and the Western film. Before concentrating on the two most prominent Western displays, those of Colorado and California, we introduce this argument with two other westwardlooking exhibits that earned praise and recognition by displaying material achievements as aesthetically significant objects. 


\section{The Material Appeal of the Midwest}

11 The first item is the "America" locomotive by the Grant Locomotive Works of Patterson, New Jersey, a machine that may have been designed with the Paris Fair in mind, but was destined for Western travel and was put in service after the Fair on the Chicago, Rock Island and Pacific Company, linking Chicago to Omaha in 1869. In Paris the American engine was met with high praise and a gold medal (Usher 110). In the description published by the semi-official L'Exposition illustrée-penned by one named A. Malespine, apparently an American agent in Paris in the 1860s-the locomotive is lauded as an example of American practicality and as a feat of decoration: "it is a monster and it is a beauty; a hell and a jewel" (Malespine, "Annexe," 396-397). Mechanically the America exhibited no major innovations, but it was adapted to the rough Western terrain. It was lighter, more flexible, and faster than European engines; it had fewer points of contact with the track and its set of small front wheels enabled it to negotiate sharper curves; its wheels of cast iron were hollow; it featured a powerful headlight and a "cow-catcher" that also served as "snow-plough" (Figure 3); and its cab was a fully-closed and outfitted cabin, decorated with panels of precious woods, from which all operations of the engine could be commanded. The mechanical features associated themselves readily with imaginations of difficult terrains, long distances, rough encounters, popularized by narratives of travel in the Wild West. But what made the America truly iconic was its extraordinary amount of ornamentation, which, according to one testimony, made it "a poem in iron and silver" (Bianculli 21): it was entirely plated in "German silver," a copper alloy with a glistening gray appearanceand, according to the American commissioner, "a surprise to continental minds [...] imbued with exceedingly plain ideas on the subject of locomotive ornamentation" (William S. Auchincloss, Report upon Steam Engineering, in Blake, 1870, vol. 4, 12). Beyond such complacent eulogia, there was enough contrary opinion to ridicule the America's excess of decoration, making it a classic example of contradictory perceptions generated by the Expo-as well as by American engineering fashions of the Victorian era (Kasson 155-159). Other testimonies, however, suggest that European opinion was not insensitive to this demonstration of what might be called an environmental aesthetics, in the shape of a sophisticated machine whose appeal was partly derived from association with a specific (and exotic) natural terrain. In shaping French perceptions of the West, the America had three major characteristics. It was an American invention and a work of boosterism, not a French appropriation; but it drew popular curiosity. It was perceived as "gaudy," but also as functional. Finally, as later iconography would make plain, it embodied the economic and social appeal of the new lands. 


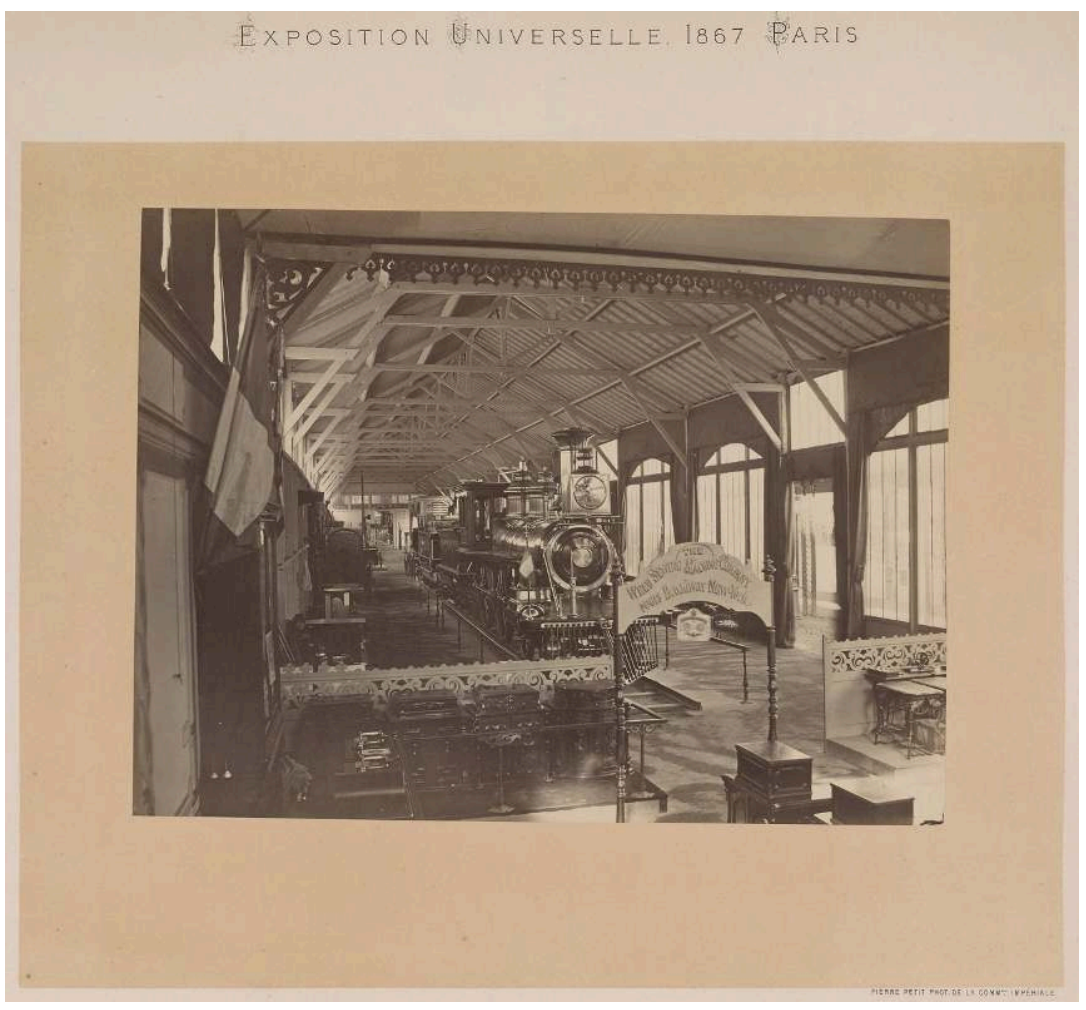

Pierre Petit, View of the American Annex with the "America" locomotive, photographic print on paper mounted on card, from Petit-Hewitt album, "Photographs of the American exhibits on display at the Exposition," 1867.

Courtesy of the Smithsonian Libraries, Washington, D.C.

12 Another striking example of early Western attempts at a primitive stage of a "form follows function" aesthetics is the highly successful Illinois representation, which was also significant symbolically, as showcasing a kind of geographical gateway and industrial precursor of the newly developing West. Illinois, a state since 1818, was by 1867 the most populous Midwestern state, which had been a major contributor to the Union Army during the Civil War; its main city, Chicago, was by 1870 the second largest city of the Midwest with 300,000 people. Probably as a result of Illinois's major investment in the Civil War, it was generously represented at the Fair. Illinois presented many samples of natural and farm products, as well as agricultural machines in the Annex and two buildings and their contents in the Fair's park. McCormick reapers garnered not only a grand prize (like in every other Fair since 1851) but also the Legion of Honor for the inventor. Other successes included Deere and Woolridge ploughs, as well as the Schuttler lumber wagon. The prefabricated Illinois schoolhouse and farmer's cottage (the interior of which displayed maps, photographs and documents on Western agriculture) both received silver medals. They could be considered "icons of American ideology" (Weiss 164)-i.e. concrete embodiments of the doctrine of self-reliance and its special connections to farming and education-and, more specifically, symbols of the hope of Western prosperity and opportunity. "Showing that luxury in the new world was to be found in simplicity and space" (Weiss 164), they were exemplars of the simple, robust construction adapted to the necessities of new lands, in striking contrast to the highly elaborated Oriental buildings-the Egyptian temple, the Mosque, etc.-that surrounded them in the park (Figure 4) (see 
Beckwith 308-310; Usher 113; Weiss 164-166). A similar point can be made about the exhibits from Louisiana, which included a "portable cottage," many examples of farm products, and a splendid set of photographs of New Orleans by Theodore Lilienthal, displayed as specimens of the economic potential of a state that, after being devastated by the Civil War, attempted to present itself in Paris as another new land (Van Zante 20-22). From Illinois (and Missouri) to Louisiana, the many examples of American boosterism gathered in Paris provide a transition to the new aesthetic identity that attached itself in Paris, more specifically, to the Far West. While this new identity was by no means a fixed one, it was reflective of the quickly evolving region, its people, and its wealth of untapped resources, all presented and received especially under the guise of photographic landscapes. It was this vision that Malespine evoked in the closing of his article on the American exhibition: "We have before us the immensity of dream and ideal; it has before itself the immensity of nature yet untamed" (Malespine, "Annexe," 398).

Figure 4

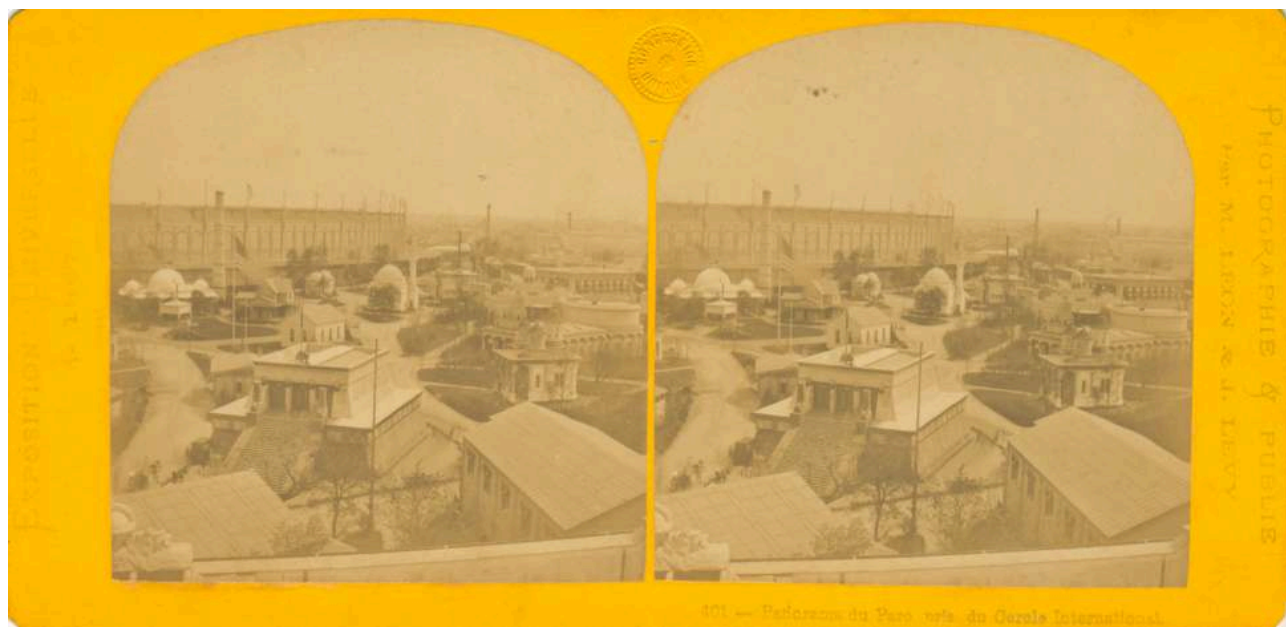

LÉON ET LÉVy, EXPosition UNIVERSELLE de 1867, NO. 401, « PANORAMA DU PARC PRIS DU CERCLe INTERNATIONAL ", STEREOSCOPIC VIEW ON PAPER ON CARD MOUNT. IN RECEDING ORDER FROM FOREgROUND TO THE LEFT, ONE SEES fIRST THE MEXICAN TEMPLE, DWARFINg THE BOSTON BAKERY AND THE ILLINOIS SCHOOLHOUSE AND FARMHOUSE (NEXT TO THE US FLAg); ON THE RIgHT, WE MAKE OUT, AMONg OTHER CURIOSITIES, THE RUMANIAN PAVILION, THE EgYPTIAN OKEL AND THE OTTOMAN MOSQUE. IN THE BACKgROUND IS THE SILHOUETTE OF THE PALACE OF INDUSTRY.

Private collection

\section{The Rich Landscapes of the Far West}

13 In the Paris Exposition, displays from the Far West-defined as the region comprising the Rocky Mountains and the Pacific Coast-mostly belonged to the groups comprising ores, foods, and cereals. As the introductory volume to the American report noted: "California, Nevada, Idaho, Colorado, Arizona, Montana, Dakota, New Mexico, Oregon, and Washington, with a united area equal to the whole of Europe, nearly all sent specimens indicative of their marvelous resources in gold, silver, copper, lead, iron, coal, petroleum, and other minerals." It stated that the U.S. mineral displays were "one of the most important features of the exhibition," and that "the most prominent collections" were those issuing from California, Colorado, and Nevada (Blake, 1870, vol. 
1, 273). ${ }^{13}$ The rich exhibits of minerals, and especially of precious metals, constituted the strongest economic force behind the Western presence in Paris. They were presented, however, within the greater context of Western boosterism which, leaving out the intrigue of Native Americans almost entirely, evoked an environmental aesthetics that linked raw materials and their transformation, promises of wealth and civilization "shooting up" from the ground, with stunning photographs of pristine landscapes. We concentrate on the displays of Colorado and California because those were the most prominent among not only Western states and territories but even the US representation as a whole; and furthermore, because they strikingly combined photographs of landscapes with natural and material objects.

\section{Colorado}

The Colorado exhibit was perhaps the most well-organized of all the American displays. While the Federal government was in the midst of attempting to organize a commission for the Territory, the title and responsibility of commissioner were seized by investor and promoter Joel P. Whitney, who opted to sponsor the Colorado display with his private wealth in hopes of spurring European interest in the burgeoning economy. The Boston mining speculator's motivation resulted in a sizeable and impressive display of silver and gold ores framed by a collection of 36 photographs and 14 maps of the region, which became one of the Expo's attractions (Figure 5). In a later reminiscence Joel Whitney boasted that, once arrived in Paris, he had taken control of the American displays and managed to place his hundreds of rocks-ores of silver and gold-in or near the "centre reserved for pianos, paintings and works of art," as Beckwith allegedly complained, rather than in the annex where it otherwise should have been situated alongside machinery and minerals (Whitney 177). Available installation photographs show that, in fact, the Colorado display occupied-though not "the very centre of the American department," as Whitney claimed-a substantial and probably strategic corner area of the mineral section (Figure 6). "Whitney had the cases covered with blue velvet cloth and glass casing, an idea which appealed to Commissioner General Beckwith, who gave orders to have all shelves in the mineral department so decorated [...]" (Leyendecker 9). It seems that Whitney, with his lavish display and accompanying photographs, was attempting to align the material appeal of the West, visually and categorically, with the more artistic displays that occupied the center of the French Exposition. 
Figure 5

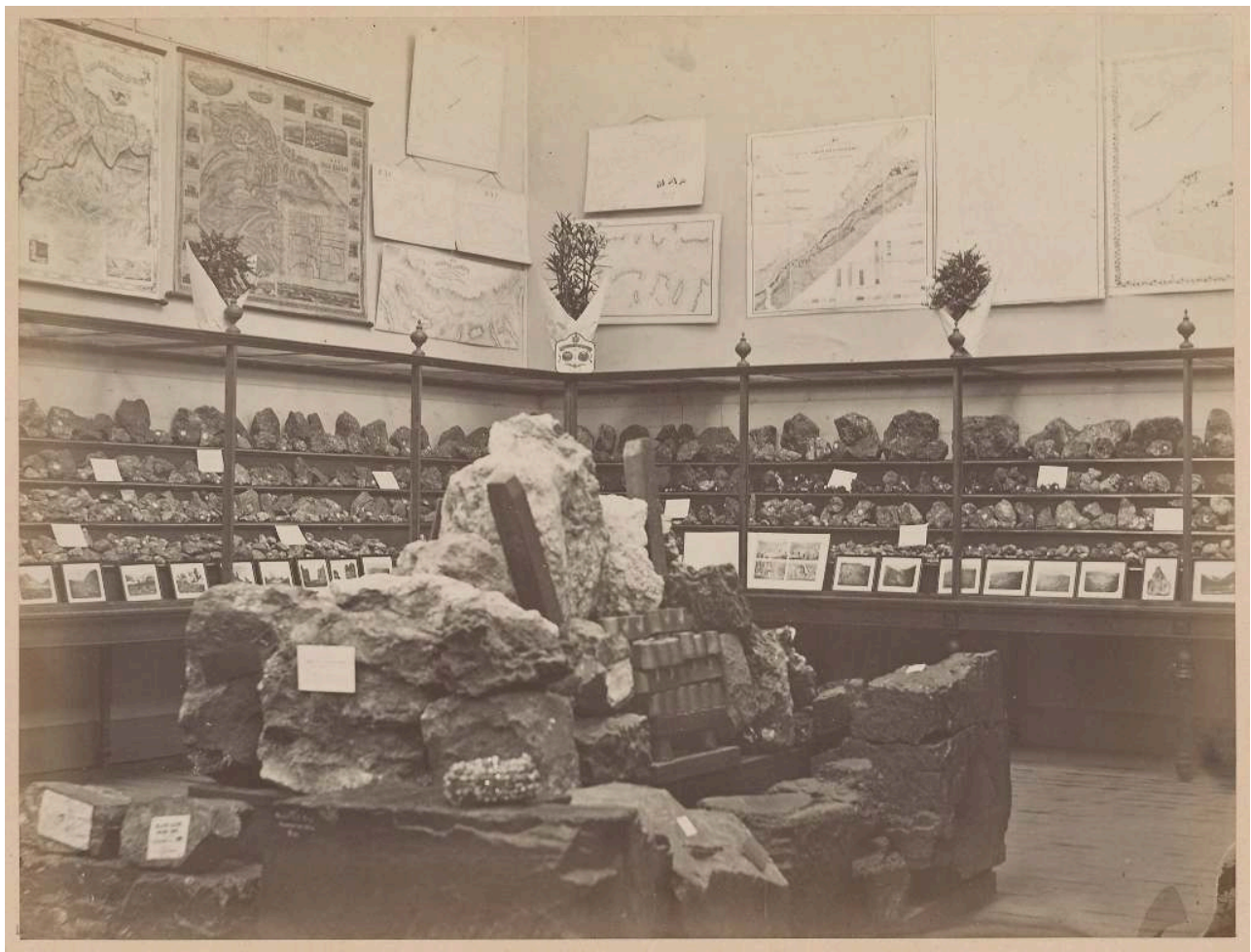

PIERRE PETIT, VIEW OF THE COLORADO ORES EXHIBITION, PHOTOgRAPHIC PRINT ON PAPER MOUNTEd ON CARD, FROM PETIT-HEWITT ALBUM, “PHOTOgRAPHS OF THE AMERICAN EXHIBITS ON DISPLAY AT THE EXPOSITION," 1867.

Courtesy of the Smithsonian Libraries, Washington, D.C. 


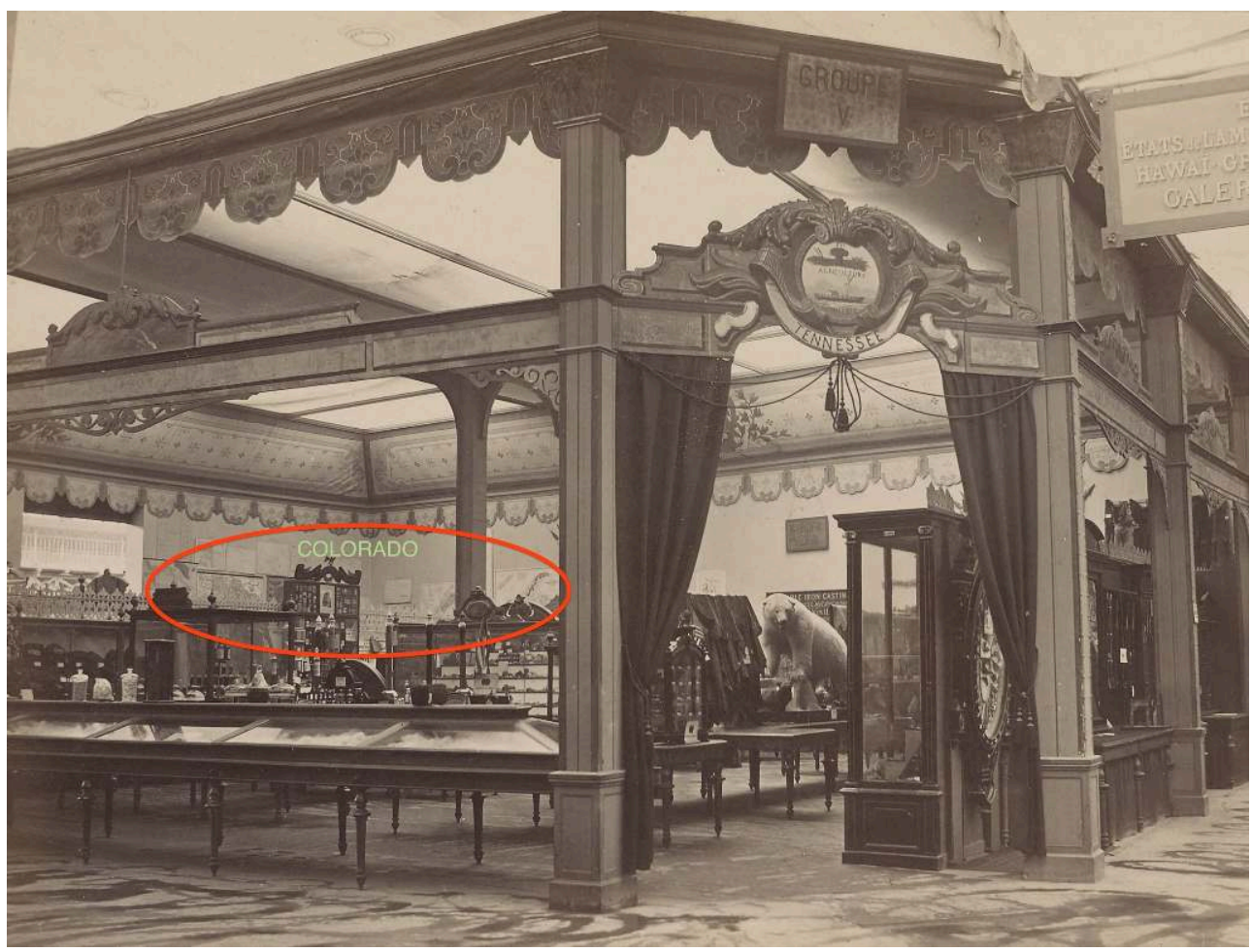

PIERRE PETIT, VIEW OF AMERICAN EXHIBIT FROM GROUP V (PRODUCTS, RAW AND MANUFACTURED), PHOTOGRAPHIC PRINT ON PAPER MOUNTED ON CARD, FROM PETIT-HEWITT ALBUM, “PHOTOgRAPHS OF THE AMERICAN EXHIBITS ON DISPLAY AT THE EXPOSITION," 1867. DETAIL SHOWING LOCATION OF COLORADO ROOM IN RELATION TO GROUP V EXHIBITS.

COURTESY OF THE SMITHSONIAN LIBRARIES, WASHINGTON, D.C.

The majority of the photographs were the work of an otherwise little-known photographer, George Wakely. They included images of mining sites and settlements as well as the scenic mountain landscapes surrounding the areas of extraction including the Garden of the Gods, Twin Lakes, and Monument Creek sites. In Pierre Petit's remarkable photograph of the Colorado exhibit we make out these photos, framed in black walnut, lining a lower shelf (Figure 7).

Figure 7

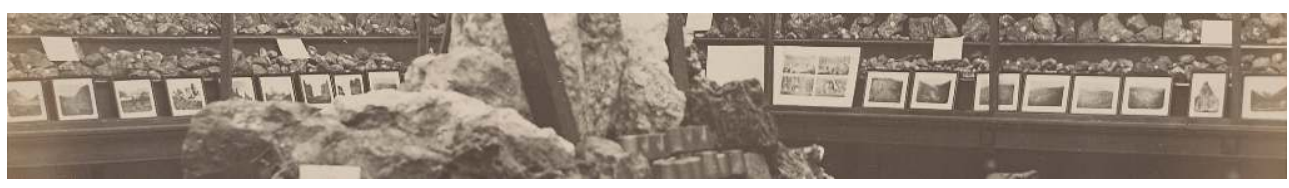

DETAIL OF FIgURE 5, SHOWINg LANDSCAPE PHOTOgRAPHS (BY GEORgE WAKELY AND OTHERS) LININg A SHELF ACROSS THE COLORADO ROOM.

COURTESY OF THE SMITHSONIAN LIBRARIES, WASHINGTON, D.C.

16 Landscape views such as "Twin Lakes" and "Garden of the Gods" (Figure 8) were already being praised in 1865, in the American Journal of Photography, as "among the most charming natural scenes in the world" (Seely 336; Palmquist and Kailbourn 575). For Malespine, the "excellent idea of attaching to the ores very pretty photographs, representing the sites neighboring the mines" contrasted to his overall disappointment with the American section (Malespine, "Exposition," 194). Whitney had a pamphlet on 
the ores of Colorado published in English, French and German, and printed 15,000 copies in the hopes of spurring interest. His effort was a success, earning a gold medal and personal visit of the Emperor to his "ores" room. It resulted in his association with various Parisian investors and dignitaries, including the traveler, ethnographer and Americanist Louis Simonin (Karel 750-753), who in the fall of 1867 embarked on a trip to the Rockies along with Whitney and William Heine, a German traveler and philanthropist who had joined the Union army in the Civil War and now served as US Consul in Paris. A four-part narrative of this trip was published by Le Tour du Monde in 1868 (Simonin), the first "modern" report on the American West to appear in this magazine, which was to become a prime source of narrative and illustration on the topic after 1870. This long report was richly illustrated with engravings, some of Native American subjects in a traditional sketch style, but many derived from photographs possibly procured by Whitney, which the firm Hachette had electrotyped (Figure 9); these photographs might well be the set, now lost, which $\mathrm{W}$. Heine reportedly gave the Paris Sociéte de Géographie in 1868, the first entry of American photographs in that collection (Brunet-Griffith 27, 124).

Figure 8

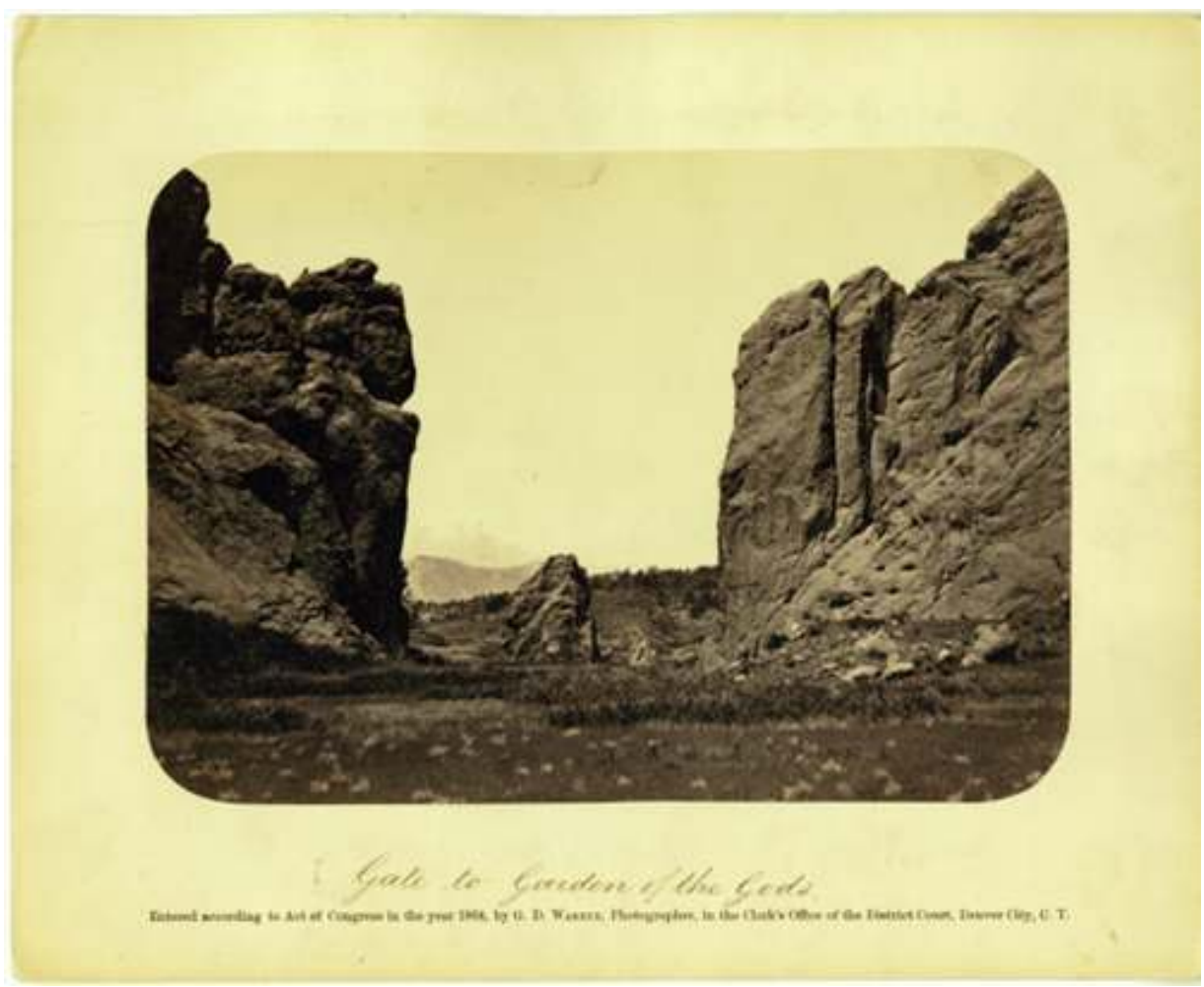

GEORgE D. WAKELY, "GATE TO GARDEN OF THE GODS," PHOTOgRAPHIC PRINT ON PAPER MOUNTED ON CARD, 1864.

HISTORY COLORADO ONLINE COLLECTION, 92.3.62. 


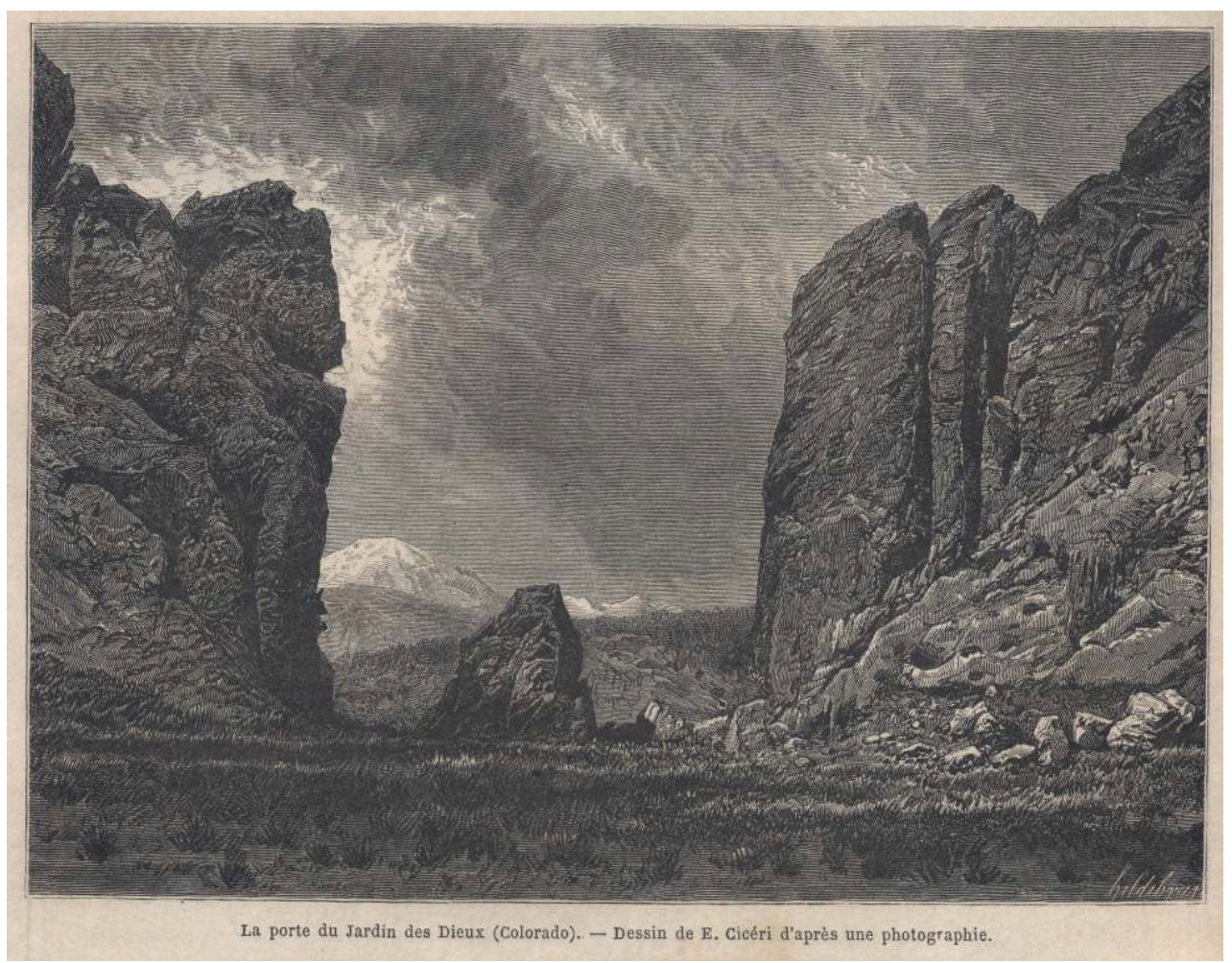

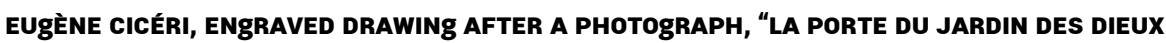
(COLORADO)."

ILLUStration In LOUIS SIMONIN, “Le far-West AMÉRICAIN," 252.

Whitney's boostering spirit is to thank for these results, though of course he did not singlehandedly create the trend of a new "aesthetics of the West," where pictorial appeal met economics and geography, and of which photography became the signal medium in 1867. The Colorado exhibit foreshadowed the use and popularity of landscape photographs to come. Whitney was utilizing photographs (without crediting the photographers) as documentary or environmental illustrations-and the total absence of any commentary on Wakely's pictures shows that they were received as such-but more importantly he also used a landscape that invited fascination as advertisement for a regional economy that was still struggling.

\section{California}

By far the most populous western state in 1867, California had evolved from temporary Gold boom to a more permanent mining and agricultural economy. Though isolated from the East until the transcontinental rail connection in 1869, the objects sent by California formed the largest and most varied collection from the West. Again, almost all of them fall primarily in the category of natural resources or products very closely linked to the land. Contrary to Colorado, California marshaled a vast array of exhibitors, and in fact acted, under Commissioner William P. Blake, as representative for the interest of Western territories more generally. Among the more than thirty displays were included cereals and minerals, but also wines, hops, glass jars and bottles, ropes and cables, woolen textiles, soap, various mechanical appliances as well as a 
number of publications and several sets of landscape photographs-by Carleton Watkins and the firm Lawrence \& Houseworth (acting as publishers for Charles L. Weed)-that formed one of the American exhibition's main attractions, and received bronze medals. ${ }^{14}$

\section{Figure 10}

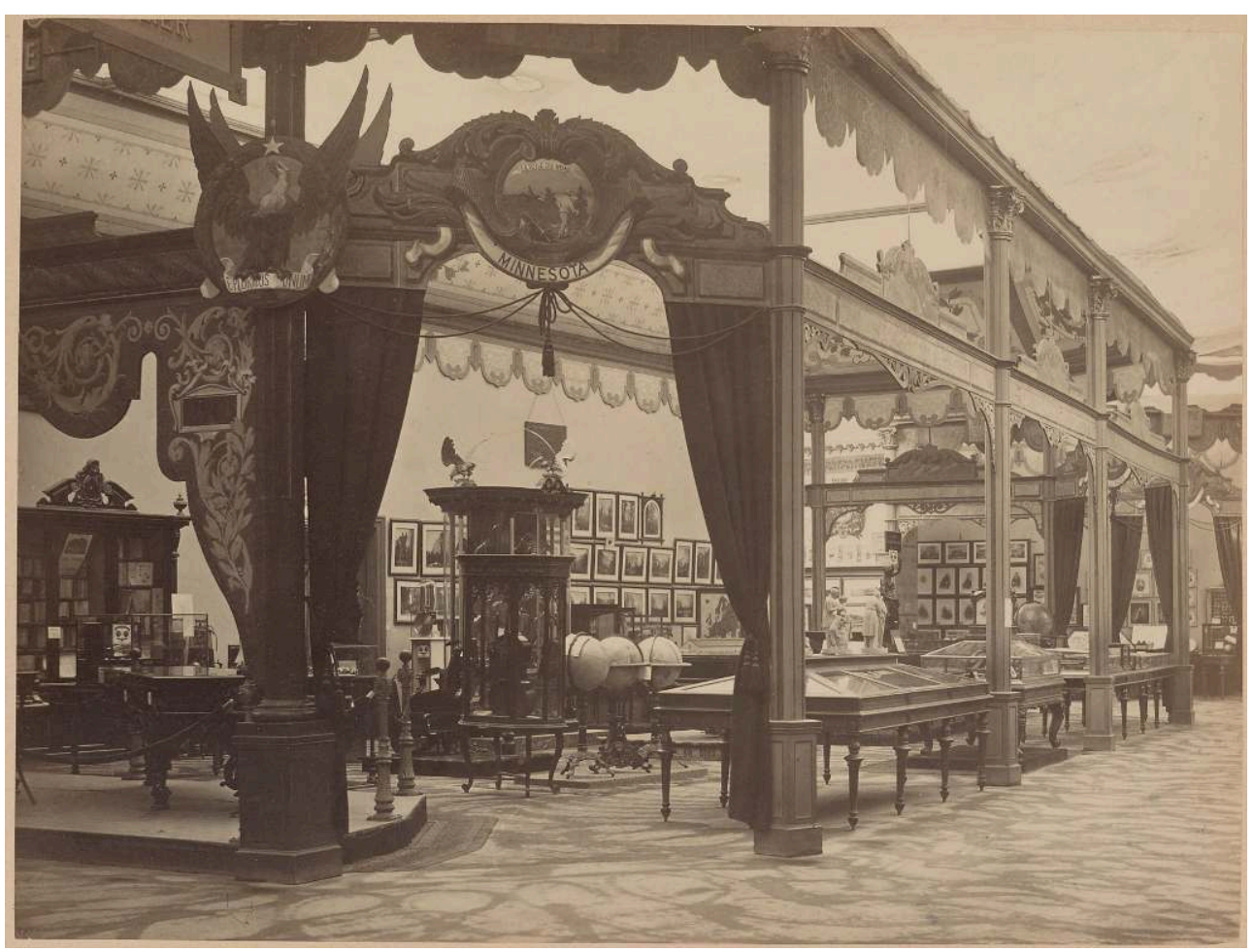

COURTESY OF THE SMITHSONIAN LIBRARIES, WASHINGTON, D.C. 


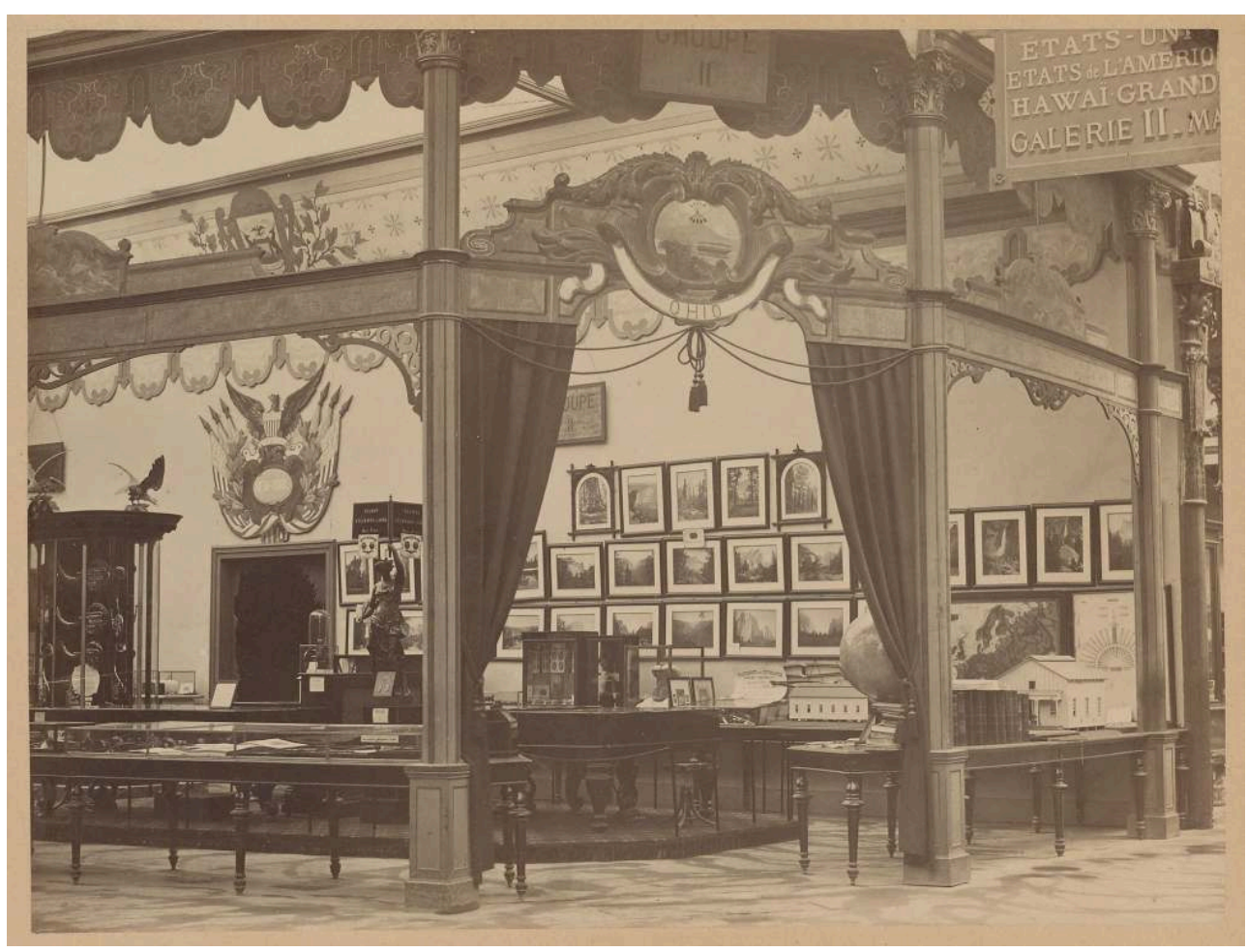

FIgURES 10 AND 11. PIERRE PETIT, TWO VIEWS OF THE ROOM OF AMERICAN EXHIBITS IN GROUPS II AND III, SHOWING VARIOUS OBJECTS AND INSTRUMENTS AND THE DISPLAY OF CARLETON E. WATKINS'S PHOTOgRAPHS OF CALIFORNIA SCENERY ON THE WALL, PHOTOgRAPHIC PRINTS ON PAPER MOUNTED ON CARD, FROM PETIT-HEWITT ALBUM, “PHOTOgRAPHS OF THE AMERICAN EXHIBITS ON DISPLAY AT THE EXPOSITION," 1867.

COURTESY OF THE SMITHSONIAN LIBRARIES, WASHINgTON, D.C.

The California photographs were not directly linked to the mineral wealth of that state; rather they were associated with the woods. Watkins's photographs of Yosemite Valley and the great trees of Mariposa, elegantly framed-those of the trees, noted William Blake, "in the wood of the trees appropriately carved" (Blake, 1870, vol. 1, 260)-, were hung very conspicuously on the long wall of the main American exhibition room in the Palace, the only one that warranted two different photographs in Pierre Petit's semiofficial coverage (see Figures 10-11), in which they came off at a striking advantage over not only the other objects in that room (pianos especially) but also over the American paintings in photos of the Fine Arts gallery. One of the views shows them right next to a striking door panel that was probably John Boyd's exhibit of a wooden door, "being most highly finished and polished so as to bring out the beautiful natural grain of the wood of the Madonna or California Laurel used in its construction" (Blake, 1870, vol. 1, 265) (Figure 12, detail). The photographs of Watkins, so strategically placed, garnered praise from several quarters. Hermann Vogel, the German authority on photography, noted, "the general public care little about the moon [in Lewis Rutherford's astronomical photographs], and enjoy more by far the fine landscapes of Watkins, of California." Vogel nailed down the general appeal and importance of Watkins' images: "America, he went on, is still to us a new world, and anything which gives us such a true representation as a photograph, is sure to be looked upon with wondering eyes" (Vogel 173). Petit's photograph (Figure 11) centers on Watkins's display at the fair, featuring the great trees of Mariposa along the top and the Yosemite 
landscapes beneath. Watkins was among the first photographers to intend his images for the wall, and to present them this way very early on. This was a new kind of art, as Douglas R. Nickel explains, referring to Watkins: "documented instances of large photographs functioning in the nineteenth century as art for the wall are relatively rare. This suggests a conception of the medium that adjudges it a new, artistic, third term-neither painting nor traditional "private" view-and its maker, by extension, a new kind of artist" (Nickel 24). Thus we may assume that viewers were drawn to this view of the West, not only because of Yosemite's unspoiled magnificence or the great trees' immensity (of which Californian organizers had hoped but failed to send a sample), but because these photographs were successful in presenting it to them. In this way Watkins's display inaugurated a type of artistically minded documentation that would come, soon after the Fair, to be a trend in geographical photography. Meanwhile, the firm Lawrence \& Houseworth also supplied a great many photographs and stereoscopic views of California and Nevada landscapes, towns and mining sites. Several sets of these images were donated by the California commissioner William Blake, at the Exposition's close, to French and European institutions, including the Société Française de Photographie (Figure 13), the Jardin des Plantes and the British Museum (Blake, 1870, vol. 1, 260). ${ }^{15}$

Figure 12

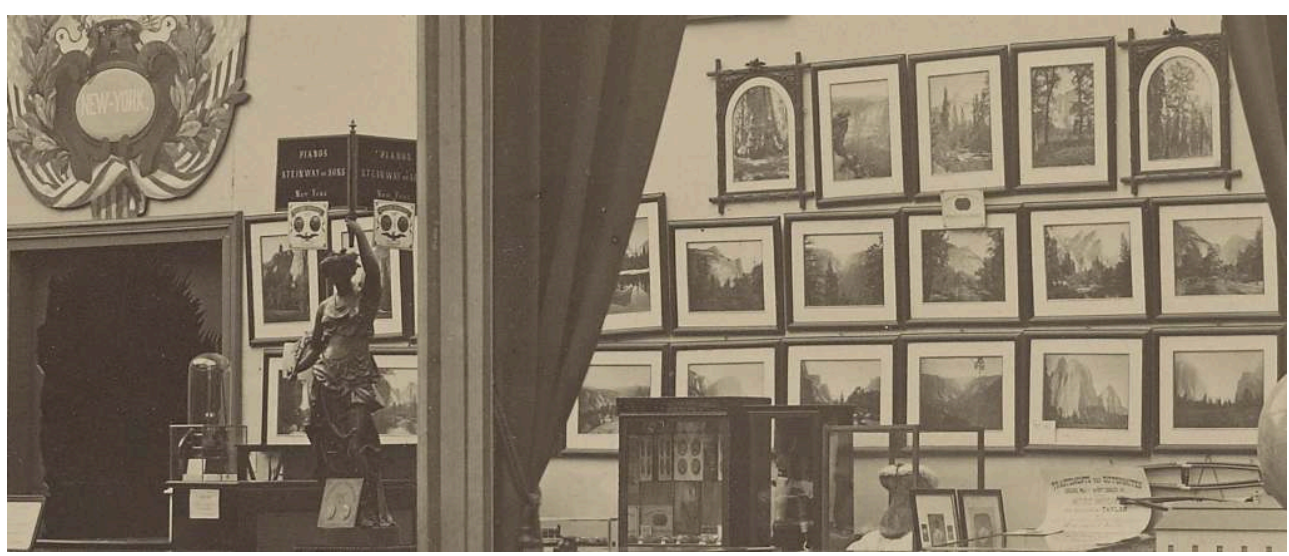

Detail of Fig. 11, showing what is probably Boyd's door (on the left) next to Watkins's display COURTESY OF THE SMITHSONIAN LIBRARIES, WASHINGTON, D.C. 


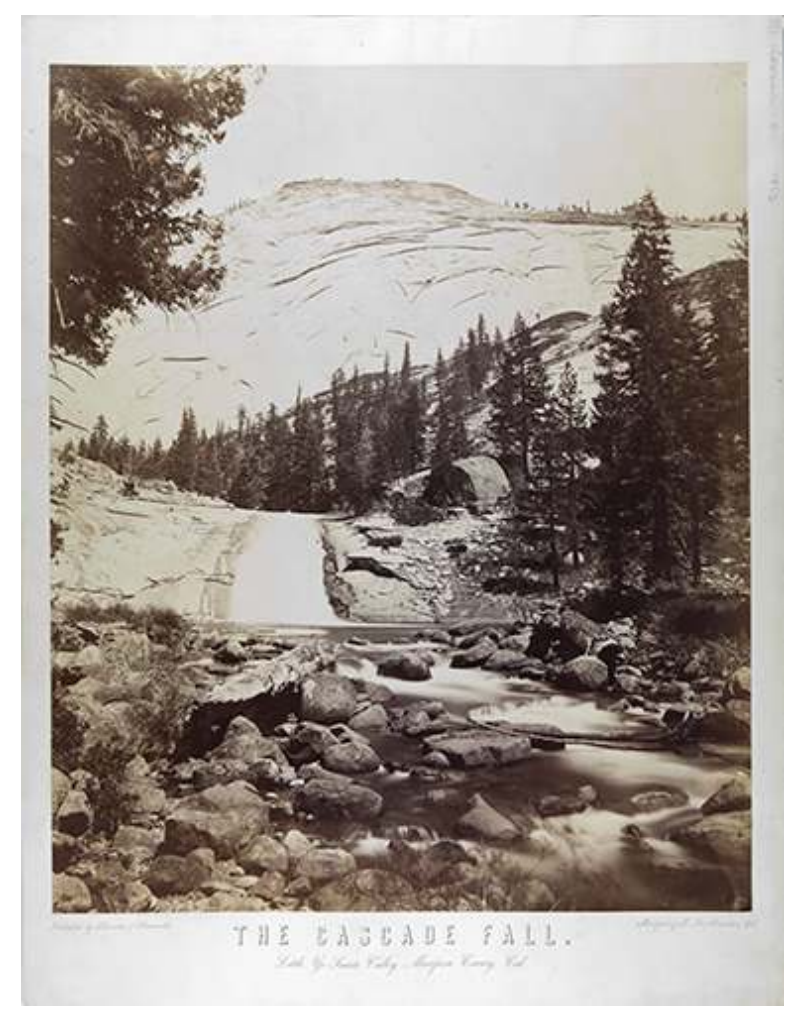

LAWRENCE \& HOUSEWORTH, “THE CASCADE FALL, LITTLE YO-SEMITE VALLEY, MARIPOSA COUNTY, CAL.", CALIFORNIA, CA 1867, POSITIVE PRINT ON PAPER. COLLECTION SOCIÉTÉ FRANÇAISE DE PHOTOgRAPHIE (COLL. SFP). (FRSFP_0237IM_EP_0003).

This print is part of a lot donated to the SFP at the close of the 1867 Exposition.

\section{Conclusion}

Around the time of the 1867 Fair, in a context of increasing industrialization, urbanization, and alphabetization, the West was "no longer a field for reflection or recreation for elites, and its aura expanded considerably" (Villerbu 95). Beyond the Cooperian imagination of the Romantic, undefined West, the photographs of Western landscapes exhibited in Paris in connection with the promise of Western economic prosperity carried this aura and introduced to European audiences a new aesthetics of the West, which tentatively extended to the whole of the American republic, following the pattern studied by the landmark 1991 Smithsonian exhibition The West as America. While the taste for Indian romance would return later on, transformed into a circuslike spectacle and staple of mass culture with Buffalo Bill's Wild West Show, this moment marked a beginning for the proliferation of a more technical and material Western aesthetics. It is therefore more adequate to speak of a complexification, or fragmentation, of perceptions, rather than of a mere evolution. It is tempting to consider that in Paris in 1867 there were several Wests being proposed to several different audiences-including experts of engineering, mining, and construction, as well as amateurs of landscape photography-and that the former abstraction of the Romantic West (echoed in Ward's statue of the Indian Hunter) was just one of them, actually receding behind more tangible portrayals of lands represented by appealing concrete objects and images. It is important, again, to relate this trend to a concerted 
effort of exhibitors, rather than to French appropriation-as well as to the rise of the new culture industry of landscape photography.

In a book published in 1867, Subterranean Life, Louis Simonin gave an account of the abundance of subterranean wealth along the entire Cordillera, which he found particularly exemplified by the Eldorado of California, Nevada, and now Colorado. At this time one of the principal French collectors of Amerindian pictures and artifacts, Simonin made no mystery of a fascination for "this beautiful California," its poetically named Golden Gate, its mining towns, shot up "as if by enchantment" and now "opulent cities"-a California that "made itself" "away from the absent-minded gazes of Europe" that still saw only the "agitated" theater of primitive immigration (Simonin, 1867, 391-392). The photographs of California and Colorado, which Simonin reproduced in his illustrated series for Le Tour du Monde in 1868 (Figure 9) were examples of a new vision, a new aesthetics of the West that contrasted with his descriptions of the "agitated" theaters of settler societies (a la Vigilante-driven San Francisco of the 1850s), as well as looming specters of the Civil War and European strife. In striking contrast to the failure of the American Fine Arts section, where a new aesthetics based on "unconventionality" had been expected and yet was found lacking, the photographs and the natural and material objects that surrounded them came to embody this new aesthetics-in spite, or perhaps because, of their ambiguous agency as mere evidential documents or advertisements (Wakely) or self-proclaimed works of art (Watkins).

The display of these Western photographs, finally, inaugurated a trend that pushed geographical imageries, especially of so-called new lands, into greater visibility. Although one cannot draw a direct causal connection to the Fair, in the US, the production of what came to be called geological photographs would increase greatly, after 1867, under the aegis of the great Federal surveys of the West. The massive output of photographs produced by these surveys-especially landscape views-would come to Europe in large amounts in the 1870s, being widely reproduced in the illustrated press and making repeated and remarked public appearances, particularly at the Vienna World's Fair of 1873. At this Fair, one found in the "graphic arts" section (Group 12), much like in 1867, the work of Watkins, Lillienthal, the Lawrence \& Houseworth Firm, Eadweard Muybridge, the Anthony Firm, Charles Bierstadt, and others, receiving more awards than even in Paris. Like in Paris, contributors also displayed photographs in other categories, including Civil Engineering, Agriculture, and Education. Just a couple of years later, on the occasion of the 1875 International Geographical Congress in Paris, Western photographs came to form the nucleus of the later formidable photographic collection initiated for the French Société de Géographie by its English-born secretary James Jackson (Brunet and Griffith 124; Brunet 2011, 189, 193). Our conjecture then is that Western photography, natural specimens and material culture of the post-Civil War era contributed to renovating the French and European view of Americasubstituting specific objects and pictures for an abstract idea and creating, for the first time, perhaps, a strong aesthetic appeal for American pictures that were no longer the clichés understood by the phrase "American images." The Paris World's Fair of 1867 may have been a seminal moment for Western American iconography, but it also seems to have been a pivotal moment in the use of geographical imageries, and their ability to link economic and aesthetic values. 


\section{BIBLIOGRAPHY}

ANONYMOUS, "Lettre de New York," Revue internationale de l'art et de la curiosité, t. 3, No. 1 (January-June 1870), 518-519.

BARREYRE, Nicolas, L'or et la liberté. Une histoire spatiale des États-Unis après la guerre de Sécession, Paris, Éditions de l'EHESS, 2014.

BARTH, Volker, "The Micro-history of a World Event: Intention, Perception and Imagination at the Exposition universelle de 1867," Museum and society 6:1 (March 2008), 22-37: http:// www2.le.ac.uk/departments/museumstudies/museumsociety/documents/volumes/barth.pdf BAUDELAIRE, Charles, Oeuvres complètes, ed. by Claude Pichois, Paris, Gallimard “Pléiade," vol. II (1976).

BECKWITH, Nelson M., Paris Universal Exposition, 1867, Reports of the United States Commissioners, General Survey, Washington, Government Printing Office, 1868.

BIANCULLI, Anthony J., Iron Rails in the Garden State: Tales of New Jersey Railroading, Bloomington, Indiana University Press, 2008.

BLAKE, William P., ed., Reports of the United States Commissioners to the Paris Universal Expositions, 1867, 6 vol., Washington, DC, Government Printing Office, 1870.

BLAKE, William P. Report upon the Precious Metals, Washington, U.S. Government Printing Office, 1869.

BRUNET, François, and GRIFFITH, Bronwyn, eds., Images of the West, Survey Photography in French Collections, 1860-80, Giverny, Musée d'art américain Giverny/University of Chicago Press, 2007.

BRUNET, François, "Showing American Geography Abroad: The International Reception of the King Survey work,” in Keith F. Davis and Jane L. Aspinwall, eds., Timothy O'Sullivan: The King Survey Photographs, Kansas City, Hall Family Foundation and Nelson-Atkins Museum of Art / Yale University Press, 2011, 185-193.

CABAU, Agathe, L'iconographie amérindienne aux Salons parisiens et aux Expositions universelles françaises (1781-1914), Ph.D. dissertation in Art history, Paris, Université Paris 1 Panthéon Sorbonne, 2014.

CARRÉ, Anne-Laure, et al., eds., Les Expositions Universelles en France au XIXe Siècle. Techniques. Publics. Patrimoines, Paris, CNRS Editions, 2012.

CHARLE, Christophe, Discordance des temps. Une brève histoire de la modernité, Paris, Armand Colin, 2011.

CHESNEAU, Ernest, Les nations rivales dans l'art, Paris, Didier, 1868.

CHEVALIER, Michel, ed., Exposition Universelle de 1867 à Paris. Rapports du jury international, 13 vols., Paris, Dupont, 1868.

COHEN-SOLAL, Annie, Painting American: The Rise of American Artists, Paris 1867-New York 1948 (French ed. 2000), New York, Knopf, 2001.

CONWAY, Moncure Daniel, “The Great Show at Paris”, Harper's Monthly Magazine, vol. XXXV, 1867, 238-253. (online: https://babel.hathitrust.org/cgi/pt?id=msu.31293016847034;view=1up;seq=9) 
DEMEULENAERE-DOUYÈRE, Christiane and Liliane Hilaire-Perez, eds., Les Expositions universelles. Les identités au défi de la modernité, Rennes, Presses universitaires de Rennes, 2014.

DIXON, W.H., “Un village américain”, transl. by “O.S.”, Revue britannique, 1875, No. 3, 327-336. DUVERGIER DE HAURANNE, Ernest, Huit mois en Amérique, Lettres et notes de voyage [1864-65], 2 vols., Paris, Librairie internationale, 1866.

ETIÉVANT, Camille, “Les Indiens à Paris,” Le Monde Illustré, t. 21, No. 533 (27 July 1867), 52-53. Exposition universelle de 1867 à Paris, Catalogue officiel des exposants récompensés par le jury international, Paris, Dentu, n.d.

FLAUBERT, Gustave, Correspondance, ed. J. Bruneau, Paris, Gallimard "Pléiade", 1988, vol. III. FONER, Eric, Reconstruction: America's Unfinished Revolution, 1863-1877 (1988), new ed., New York, HarperCollins, 2014.

GONCOURT, Jules et Edouard de, Journal des Goncourt, ed. Robert Ricatte, Paris, Laffont "Bouquins," 1989.

HAMON, Philippe, "Images à lire et images à voir: 'images américaines' et crise de l'image au XIX siècle (1850-1880)," in Stéphane Michaud, Jean-Yves Mollier, and Nicole Savy, eds., Usages de l'image au XIX ${ }^{e}$ siècle, Paris, Créaphis, 1992, 235-248.

HARVEY, David, Paris Capital of Modernity, $2^{\text {nd }}$ ed., New York, Routledge, 2005.

KAREL, David, Dictionnaire des artistes de langue française en Amérique du Nord, Montréal, Presses de l'Université de Laval, 1992.

KASSON, John F., Civilizing the Machine: Technology and Republican Values in America, 1776-1900, new ed. New York, Farrar, Straus and Giroux, 1999.

LACLOTTE Michel and Jean-Pierre Cuzin, eds., Dictionnaire de la peinture, new ed., Paris, Larousse, 2003.

LEYENDECKER, Liston E., “Colorado and the Paris Universal Exposition, 1867,” The Colorado Magazine, 46, No.1, Denver, State Historical Society of Colorado, Winter 1969, 1-15.

L'Illustration, unsigned article, t. 49,199 (30 March 1867).

MAINARDI, Patricia, Art and Politics of the Second Empire. The Universal Expositions of 1855 and 1867, New Haven, Yale University Press, 1987.

MALESPINE, A., “L'Exposition américaine," L'Exposition Universelle Illustrée. Paris, Bureau d'abonnements, 1867, vol. 1, 194.

MALESPINE, A. “L'Annexe des Etats-Unis," L'Exposition Universelle Illustrée. Paris, 1867. vol. 2, 396-397.

NICKEL, Douglas R, WATKINS, Carleton E., HAMBOURG, Maria M, Carleton Watkins, $1^{\text {st }}$ ed., San Francisco, San Francisco Museum of Modern Art, 1999.

ORY, Pascal, « Paris, capitale des expositions universelles », in Isabelle Chalet-Bailache (dir.), Paris et ses expositions universelles, architectures, 1855-1937, Paris, Editions du Patrimoine/Centre des Monuments nationaux, 2008, 8-13.

PALMQUIST, Peter E. and Thomas R Kailbourn, Pioneer Photographers of The Far West, Stanford, Stanford University Press, 2000.

PORTES, Jacques, Une fascination réticente. Les Etats-Unis dans l'opinion française, Nancy, Presses universitaires de Nancy, 1990. 
RICHARD, Gabriel, ed., L'Album de l'Exposition illustrée. Histoire pittoresque de l'Exposition universelle de 1867, Paris, Schiller, 1867.

ROGER, Philippe, L'Ennemi américain. Généalogie de l'antiaméricanisme français, Paris, Seuil, 2002.

SEELY, Charles A. (ed.), "Editorial Department," American Journal of Photography, Vol. 12, No. 14, January 15, 1865, 335-336.

SIMONIN, Louis, La Vie Souterraine, Paris, Hachette, 1867, 391-392.

---, “Le Far-West américain” (1867), Le Tour du Monde, t. 17 (1868), 225-288.

SMITH, H. N., Virgin Land; the American West as Symbol and Myth. Cambridge, Harvard University Press, 1950.

TROYEN, Carol, "Innocents Abroad: American Painters at the 1867 Exposition Universelle, Paris," American Art Journal 16/4 (1984), 3-29.

TRUETTNER, William H., and Nancy K Anderson. The West as America: Reinterpreting Images of the Frontier, 1820-1920. Washington: Published for the National Museum of American Art by the Smithsonian Institution Press, 1991.

USHER, James M., Paris Universal Exposition ; with a full description of awards... Boston, Nation's Office, $1868,113$.

VAN ZANTE, Gary, New Orleans 1867, Photographs by Theodore Lilienthal, London, Merrell, 2008.

VASSEUR, Edouard, "Pourquoi organiser des expositions universelles? Le 'Succès' de l'exposition universelle de 1867," Histoire, économie \& société, 2005: 4, 573-594.

VILLERBU, Tangi, La Conquête de l'Ouest, Le récit français de la nation américaine au XIXe siècle, Rennes, Presses universitaires de Rennes, 2007.

VOGEL, Hermann, "Paris Correspondence," The Philadelphia Photographer, Vol. 4, 1867, 172-174.

WEISS, Ellen, "Americans in Paris: Two Buildings," Journal of the Society of Architectural Historians 45, No. 2 (June 1986): 164-167.

WHITNEY, Joel P., Reminiscences of a Sportsman, New York, Forest and Stream, 1906.

\section{NOTES}

1. This article and the conference paper it is derived from stem from a group research project on the US participation in the 1867 World's Fair, to which the Smithsonian Institution's National Museum of American History (NMAH) has been a partner, notably through the input and guidance of Shannon Perich, curator of the Photographic History Collection; we express our grateful acknowledgement to NMAH for its generous contribution to the iconography of this article, in authorizing the reproduction of several little-known images from an album preserved at the Cooper-Hewitt Museum and in producing a new high-resolution scan of the floor-plan included in that album. We also wish to acknowledge the inspiring guidance and feedback of Gary Van Zante (MIT Museum); the valuable research of Clémence Guy and Manuel Sauvage during their internships for their Master's degree at Paris Diderot (English Department); Emily Burns's and Agathe Cabau's invitation to publish this contribution and their attentive editing and feedback; and the useful remarks of the anonymous reviewers.

2. On the Second Empire's Expositions, see the classic study of art historian Patricia Mainardi. For a brief summary of recent French historiography on nineteenth-century Paris World's Fairs, see Ory, 8-13. For a stimulating vision of the relationship between technology, communication, and 
heritage, see the recent volume edited by Carré et al.; and, on the transformations of "identity" through World's Fairs, the volume edited by Demeulenaere-Douyère and Hilaire-Perez. On the 1867 Exposition, see also Vasseur and more references further. For a penetrating analysis of the relationship of Expositions to the notion of modernity in 19th-century France, inspired by Walter Benjamin, see Harvey.

3. On the American context of 1867, see the classic work of Eric Foner (new ed. 2014), especially for the study of the transformation of racial relations and of an expanding, reforming Federal government. In French, the recent book by Nicolas Barreyre foregrounds the importance of the economy and financial forces, as well as the diverging agendas of regions and states in the political transformation. The principal study on the participation of the US in the 1867 Fair, outside of the Fine Arts section, is that of Gary Van Zante. Facts and figures cited come from this source and official reports.

4. In a July 1867 Harper's Monthly Magazine article that is one of the most extensive American reviews of the Fair the author Moncure Daniel Conway described the American display as an overall "failure," despite the success of "scattered objects" (including Chickering pianos, ambulances, and "the best railway car") (Conway 242); he was especially severe about the American display in the Fine arts.

5. Christophe Charle's essay, Discordance des temps centers on the notion of modernity as "discordance" (between parallel timeframes, and between various social groups).

6. Hamon quotes the "Barnum" entry of Pierre Larousse's great Dictionnaire, where the showman is defined as the embodiment of charlatanism, commercialism, and industrialism. The word humbug was adopted for a while in French, giving its title to a Jules Verne story. As Hamon concludes, "the image of America and American images are inseparably linked" (240, note 14).

7. See Baudelaire, 575-583, for the review of the 1855 Exposition, where the writer lambasted the follower of the "idea of progress," "so thoroughly Americanized by his zoocratic and industrial philosophers." In one of his last manuscripts, dated 1861 and part of the Fusées project, the same complaint took an apocalyptic form, prophesizing the end of the world, as "mechanics has us so Americanized, progress has so thoroughly atrophied in us the spiritual part" (665).

8. Beckwith expected, however, that the qualities of American products would be "adopted and reproduced" all over Europe, and that by virtue of the law of influence which he had observed in the wake of previous World's Fairs, "our products will in time acquire those tasteful and pleasing qualities" which could also further commercial success.

9. In his official report, Chesneau noted that in the New World, "the American Republic alone has been able to bring together a few noteworthy paintings" and quoted Church, Bierstadt, and Whistler again, along with "genre pictures" by Homer, Johnson, and Lambdin (Chesneau in Chevalier, Rapports, vol. I, 51).

10. Bierstadt, who exhibited again in Paris in 1869, received the Legion of Honor that year. He and Church are mentioned in several late-19th-century French biographical dictionaries. See also an article translated from the London Times in the Revue britannique (Dixon, 1875, 327). Nonetheless, up until the present, the reputation of 19th-century American landscapists in France has been rather mixed. Thus we read for instance in a recent dictionary of art that "Albert Bierstadt, Worthigton Whitteredge [sic], Samuel Robinson Gifford, Thomas Moran confuse painting with sporting achievement" as they combine "immensity of format with minute execution." (Laclotte and Cuzin, 384)

11. See also the anonymous "Lettre de New York," 1870, 518-519 (American artists are unfettered by bureaucracy and tradition).

12. L. J. Jacques, "Promenades au Champ-de-Mars," (in Richard, 28), narrates an anticipated (and entirely imaginary) visit to the "hut of the Redskin" in the park. The main record of "Indians in Paris" is found in an illustrated note signed Camille Etiévant, "Les Indiens à Paris," which talks about a performance by two members of the tribe of "Callapooses," belonging to the "American 
circus" (Etiévant 52-53); in spite of the attached illustration, the Callapooses are not recorded and the story as well as the image (a variant of which is found on a decorated souvenir china plate) are probably either fictitious or apocryphal.

13. The paramount significance of precious metals for the US commissioners is fully demonstrated by the large special report produced by the California commissioner (Blake, 1869; also included in Blake, 1870, vol. 2).

14. The French catalogue of awards mentioned Watkins's bronze medal for "Paysages" and Lawrence's and Houseworth's for "Vues photographiques" (Exposition universelle de 1867 à Paris, 36). A third entry, consisting of six albums by Edward Vischer, failed to reach the Fair.

15. Blake listed 22 large photographs of the Yosemite Valley and 4 of the mammoth trees; for stereoscopic views, 21 of Yosemite, 33 of mammoth trees, 40 of San Francisco, 17 illustrating the art of hydraulic mining, 43 of placer mining, 158 of California scenery, and 29 of Nevada.

\section{ABSTRACTS}

The Exposition Universelle of 1867 was the second of its kind to be held in Paris and was the largest to date. In 1867 the French Second Empire's "social" doctrine staged industry and labor not only as economic values but as cultural facts, envisioned in socio-ethnographic terms if not as forms of spectacle. The United States was only a second-tier player; however, for the U.S. organizers the Paris Exposition was a crucial opportunity for the country as it just emerged from the Civil War and entered Reconstruction. This paper seeks to identify aesthetic concerns and, more generally, an ambition to seduce the gaze of French and international viewers through the general organization and specific displays of the American exhibition, concentrating on exhibits offered by the Western states and territories. Images and objects from this region-particularly between the Rocky Mountains and California-played a significant, if perhaps unexpected, role in shaping a new aesthetic identity that potentially extended to the entire US exhibition. The display of Western photographs inaugurated a trend that pushed geographical imageries, especially of so-called new lands, into greater visibility. The Paris Exposition of 1867 seems to have been a pivotal moment in the use of geographical imageries, and their ability to link economic and aesthetic values. In the context of this Exposition western photography, natural specimens and material culture of the post-Civil War era contributed to renovating the French and European view of America-substituting specific objects and pictures for an abstract idea and creating, for the first time perhaps, a strong aesthetic appeal for American pictures that were no longer the clichés understood by the phrase "American images."

La deuxième du genre à se tenir à Paris, l'Exposition Universelle de 1867 reste la plus importante à ce jour. En 1867, la doctrine sociale du Second Empire français mettait en scène l'industrie et le travail non seulement en tant que valeurs économiques, mais aussi en tant que faits culturels, envisagés en termes socio-ethnographiques voire comme une forme de spectacle. Les États-Unis n'ont joué qu'un rôle secondaire parmi les pays exposants, mais pour les organisateurs américains, l'exposition de Paris présentait une occasion particulièrement précieuse pour le pays qui entrait dans l'ère de la Reconstruction, après la guerre de Sécession. Cet article cherche à identifier les préoccupations esthétiques et les stratégies de séduction des spectateurs français et étrangers déployées par les responsables américains, en se concentrant sur les expositions proposées par les États et territoires de l'Ouest. Les images et objets provenant de cette région 
ont joué un rôle important et inattendu dans la formation d'une nouvelle identité esthétique qui a rejailli sur l'ensemble de l'exposition américaine. L'exposition de photographies de l'Ouest a inauguré une visibilité accrue des images géographiques, en particulier des «nouveaux territoires ». L'Exposition de Paris de 1867 semble avoir été un moment charnière dans l'utilisation des images géographiques et dans leur capacité à associer valeurs économiques et esthétiques. Notre hypothèse est que les photographies de l'Ouest, les spécimens naturels et la culture matérielle de l'après-guerre de Sécession exposés à Paris ont contribué à renouveler la vision française et européenne de l'Amérique, substituant des objets et des images spécifiques à une idée abstraite, et créant, pour la première fois peut-être, un fort attrait esthétique pour les images américaines concrètes estompant les clichés portés par l'expression « American images ».

\section{INDEX}

Mots-clés: Ouest américain, photographie, histoire de la photographie, Exposition Universelle de 1867, Histoire de l'Ouest, échanges culturels franco-américains, photographie de paysages, culture visuelle, photographie d'expédition

Keywords: American West, photography, history of photography, Western History, FrenchAmerican cultural exchange, exhibition studies, landscape photography, Survey photography, World Fairs, Universal Exposition of 1867

\section{AUTHORS}

\section{FRANÇOIS BRUNET}

Université Paris Diderot

JESSICA TALLEY

Université Paris Diderot 